\title{
Inhabiting the Skin: Bodily Histories in Colum McCann's Transatlantic
}

\author{
Alvany Guanaes \\ NOVA-FCSH
}

\begin{abstract}
This essay intends to analyze how the body is represented to signify History and histories through the characters in the novel Transatlantic (2013), written by acclaimed Irish author Colum McCann. On the one hand, taking into account the "political economy of the body" postulated by Michel Foucault, the body may be understood as a space of social, political and historical inscription. On the other, bringing the work of Didier Anzieu about the skin ego to a literary approach, the human corporeal presence may also be taken as the mediator between History and the subjective historical experience. In Transatlantic, more precisely on the chapter entitled "1845-46 - Freeman", McCann writes about the crossing of the Atlantic done by the orator, writer, and abolitionist Frederick Douglass, also a fugitive slave, to a famine-devastated Ireland, hoping to win his freedom in this journey. Douglass marveled at the whiteness of the Irish skin as much as he was estranged for his being black. Personal, social, and historical issues are learned and resignified by the protagonist in this encounter, which is precisely the discussion focus of the present work.
\end{abstract}

Keywords: Transatlantic, Colum McCann, body, history, Frederick Douglass

Resumo: Este ensaio pretende analisar de que maneira o corpo está representado para significar a História e as histórias através das personagens do romance Transatlantic (2013), escrito pelo aclamado autor irlandês Colum McCann. Por um lado, levando em consideração a "economia política do corpo" postulada por Michel Foucault, o corpo pode ser entendido como um espaço de inscrição social, política e histórica. Por outro lado, trazendo o trabalho de Didier Anzier sobre o eu-pele para uma abordagem literária, a presença corpórea humana pode também ser entendida como uma mediadora entre a História e a experiência histórica subjetiva. 
Em Transatlantic, mais precisamente no capítulo intitulado "1845-46 - Freeman”, McCann escreve sobre a travessia do Atlântico feita pelo orador e escritor Frederick Douglass a uma Irlanda devastada pela fome. Considerado um escravo em fuga e com esperanças de conseguir sua liberdade nessa viagem, Douglass admirou a brancura da pele irlandesa tanto quanto foi hostilizado por ser negro. Questões pessoais, sociais, históricas são ressignificadas pelo protagonista nesse encontro, o que é precisamente o foco da discussão no presente trabalho.

Palavras-chave: Transatlantic, Colum McCann, corpo, história, Frederick Douglass

This essay revisits the works of philosopher Michel Foucault and psychoanalyst Didier Anzieu to explore historical signification through corporeal configurations in the Irish author Colum McCann's novel Transatlantic (2013). Foucault (1977: 24) interrogates the notion of the body being "invested by power relations" embedded in a "system of subjection" (idem: 25) to transform the body into a "force of production" (ibidem) within the social fabric. Anzieu (2016) presents a relationship between body and mind to approach human subjectivity, taking into account the skin as a mediator between people and their surroundings. Like an envelope, the skin outlines the limits between the individuals and their others and, for our purpose, the subjects and their histories/Histories. Therefore, the present analysis draws ideas from the scholars above to analyze the embodied constituents of the abolitionist Frederick Douglass after his crossing of the Atlantic to Ireland while he was still considered an escaped slave by North-American masters. Slaves held no power over their bodies as these were spaces for the exercise of sovereignty by the masters. Therefore, to cross the passage to freedom has to do with a new configuration of the body by the 'freeman.' Foucault mostly lays the groundwork for the social framework of the analysis, whereas Anzieu clarifies some metaphors employed in the text to elaborate upon the dialogue between personal and social contexts mediated by the body. 
In the chapter "1845-46 - Freeman", not only is Douglass referred to by his physical characteristics "He was broad-shouldered, muscled, over six feet tall” (McCann 2013: 41), but also his experience in a foreign land addresses the body symbolically, "He thought then that he had found the word for Dublin: a huddled city. He, too, had spent so many years, huddled into himself" (idem: 45). The meanings underlined in such textual bodily representations provided the repertoire to build a bridge between Douglass and his alterities.

Colum McCann's Transatlantic encompasses multiple stories along three centuries. Despite the time-space gap, the characters' lives in these accounts intersect in a dynamic transatlantic relation between The United States and Ireland. The novel starts in 1919 with the Alcock and Brown's inaugural non-stop transatlantic flight. The pilots set out from Newfoundland in Canada to County Galway in Ireland, establishing in Transatlantic the first encounter between North-Americans and Irish people. The second gathering, mentioned previously, revolves around Frederick Douglass's visit to Ireland during the catastrophic period of the Great Hunger. The last encounter in the novel portrays the Democratic Senator George Mitchell, who played a crucial role in the peace negotiations in Northern Ireland and Good Friday Agreement.

Such intersections are about transculturality, which offer the opportunity to build one's subjectivity within the social framework in a dialogic relationship between one's history/History and the others' histories/Histories either through similarities or differences. Nonetheless, the pivotal perspective of the present analysis is Douglass's embodied subjectivity in profound transformation during the events in which he took part while living in Ireland.

Frederick Douglass escaped slavery to live as a freeman in Massachusetts, but he still ran the risk of being arrested by slave catchers. The publication of his autobiography Narrative of the Life of Frederick Douglass (1845) put him on the spot, increasing the threat of him being caught, which is why he sought the help of abolitionists in Ireland. Mixing fictional to actual events, McCann recounts this episode in Transatlantic.

African Americans-Irish ties had long started before Douglass boarded on a ship to 
the old world. Irish Methodists, Quakers, and Unitarians met in churches to advocate the end of slavery and a Negroes' Fund was established in Dublin in 1831 whose main objective was to support actions targeting the end of slavery in the Americas. Another writer had already made his way into Irish context several decades before Douglass: Olaudah Equiano, a freed slave, living in England, had his biography published in 1791 following his visit to Ireland where he was "warmly welcomed" (Kinealy 2007: 51). Transatlantic deals with American Anti-slavery society favored the coming of Frederick Douglass to Ireland to seek help for winning his manumission.

Another translocal intersection exposed in the novel and involving the same players juxtaposes Frederick Douglass and Irish nationalist Daniel O'Connell. On one side there is Douglass in his fight to end slavery and to secure his liberty, whereas in Ireland the voice of the libertarian O'Connell echoes across the cities of Ireland advocating Catholic emancipation. Douglass is continuously referred to in the novel as "The Black O'Connell" (McCann 2013: 65, 87) and O'Connell is known to have tormented slave-masters in the Americas, as he was one of the leading voices of the abolitionist movement in Ireland. O'Connell also crossed the Atlantic, in the opposite direction from Douglass, to support the same cause of black emancipation in The United States. Both men preached over the same book and were eloquent orators who postulated non-violence. As they were so profoundly in common grounds in their posture and beliefs, such amalgamation accounts for the crossnational bonds between two oppressed people, reverberating McCann's assumptions of human condition similarities despite differences. By overlapping diverse people and places - Ireland, nations of Africa, England, The United States - McCann allows for "revisiting old or opening novel historiographic interrogations" (Jerônimo/ Monteiro 2018: 13).

The 27-year-old Douglass had then the opportunity to spread his ideas through lectures and gatherings with the advocators of his cause across the Atlantic, but it also proved to be an uneasy moment for the young orator who had many (white) eyes turned to him, men "of high collars and groomed moustaches" (McCann 2013: 49) "with an air of antiquity about them" (ibidem). Also, from the start, he was interpellated by the comforts and the constraints of being a guest: "he was not used to being waited upon" (idem: 40). His 
landlord was Richard Webb, an Irish Quaker publisher, one of the founders of the Hibernian Anti-Slavery Society in Ireland.

Douglass's hardship is demonstrated through bodily impressions. After waking from a restless sleep at Webb's house and having had a bath: "He climbed quickly from the water - the print of his wet feet on the cold floor. The towel touched, coarse, at the back of his neck. He dried the sculpt of his body" (ibidem). It is the tactile means which informs of Douglass's first experience in the new land, alluding to Anzieu's idea of the skin being a psychic envelope. A careful analysis of the passage shows some constraints of the social limbo where the protagonist was living. First, the feet perception reveals his discomfort on the new soil, which has not warmly welcomed him yet. As a support, we may refer to a further passage on which coldness is also evoked as Douglass shivers by getting closer to a pale-skinned maid (idem: 41). The coarse towel indicates the traumas he carries for having a rope around his neck during his years in captivity. Finally, his sculpted body not only does denotate a handsome figure as much as it connotates a carved image, a fake version he elaborated to deal with otherness - he was still to consolidate his status as a freeman. In the framework of African American captivity, the slave's body was the master's property - the investment of power discussed in Discipline and Punish (Foucault 1977) but in the excerpt above there is a ghostly presence of mental slavery.

Back then, Douglass was occupying a political and national limbo for being an escaped slave, and the experience of an oppressive subjugation was not to make it easy for him to break the chains. Nonetheless, there is an embedded redeeming escape in this event: Douglass set foot on the cold Irish soil, but at the same time he imprinted himself in Irish history through the "print" of his book by Irish abolitionists. Additionally, it is needed to consider its reverse: the way Ireland was to be imprinted on Douglass. A new history/History book is to be written as a result of such transatlantic cooperation - the only way to pursue and to preserve Douglass's identity.

Douglass's memories were filled with images of blood and torture, regularly invoked at the request of his hosts for a speech since the welcome dinner party as they were eager to know details about his days as a slave. More recently, he told them, during his travel from 
Boston to Dublin he was ostracized and threatened by the white people in the ship. In a way, Douglass embodied the Black Atlantic experience (see Gilroy 1993) of displacement and diaspora.

Douglass's nervous reactions felt in his spine, clammy hands, hammering heart alluding to his still subjected position in the first encounters with the Dubliners as we may see on page 42 :

The guests watched as if a carriage were galloping along but might suddenly overturn in front of their eyes. A bead of sweat rolled down between his shoulder blades. He found himself faltering. He rounded his fist, coughed into it, dabbed at his brow with a handkerchief. He had made himself free, he said, but remained property. Merchandise. Chattel. A commodity in law. (McCann 2013: 42)

Desire and insecurity overlap to rupture the elusive slave's body, and he still felt commodified. Words such as gallop, blades, fist, dab inform both of creative and of destructive violence, and such antagonism is part of a man under self-discovery while too much was expected from him, and lots were at stake in the mission of freeing the body and minds of three thousand slaves, including himself. The pain in his stomach barely allowed him to eat the exquisite lamb prepared to him. The uneaten food epitomizes his inability to internalize the other, in this case, the Irish world, whereas he was counting on strangers' "hunger for justice" (ibidem). Besides, he was still to incorporate himself as the "Lamb of God" in a messianic task as he was still a man trapped in his past: "There was a part of him that still missed the days of carpentry and caulking: fatigue, desire, hunger" (idem: 51). He did not miss the past; actually, he lacked the urge to accommodate such sensations in the current context.

Secretly, Douglass kept two tow iron barbells to exercise. Such objects had been made to him by a white blacksmith, his friend. To make them, he melted chains used to keep slaves to be sold in auction houses in an attempt "not to forget" (idem: 50). They are now objects of historical significance personifying white and black people cooperation. Once been used to keep people paralyzed, the transformed artifacts were being employed in a continuous movement aiming to muscle strength. 
He lifted the barbells one after another - first from the floor and then high in the air - until sweat dripped down onto the wood. He positioned himself to watch himself in the oval looking glass. He would not become soft. It was exhaustion he wanted - it helped him to write. He needed each of his words to appreciate the weight they bore. He felt like he was lifting them and then letting them drop to the end of his fingers, dragging his muscle to work, carving his mind open with ideas. (idem: 51)

Douglass tries to impinge on himself the familiar pain that motivated him to advocate freedom in the first place. This way, such actions allow a more constructive connotation. Foucault argues that "mastery and awareness of one's own body can be acquired only through the effect of an investment of power in the body" (Foucault 1980: 56), being muscle building one of those investments to which Foucault refers. Douglass revisits his past through physical suffering but transcends it through strength. Connotationally, every word he prints in the present context will then carry the muscular tenacity of his past, aiming to change the future. Mind and body join forces in such dynamic temporal-defying and personal task. Douglass embraced the epistemological quest of overcoming slavery but had not quite reached the ontological dimension of it through developing the conscience of a freeman.

Webb had told him that the Irish word for a black man is "fear gorm" (ibidem), which means blue man. Looking at the mirror, Douglass sees himself embodying such a description for having his face covered in ink from his feverish writing. Comparatively, his skin was tattooed with the remnants of his narrative as a substitute for the initials of the master's name branded on his skin. Therefore, although covering his body with fancy clothes may allude to a protective shield or to an attempt of looking like a local, his writing started to show he was inscribing over the marks that had been burned on his skin.

Far from the three-storey houses and their elegant inhabitants, Douglass runs into poor people where "the streets narrowed" and "the filth was staggering" (McCann 2013: 44). Such vision dawned on him as a surprise as he had no idea people lived in precarious conditions so similar to what he well knew and maybe worse. The whiteness that had previously made him shiver, this time aroused sympathy: "The poor were so thin and white, 
they were almost lunar" (idem: 46). Getting to know more about present Irish context and realizing similarities between Dublin and his scenario allowed him to see both white and black skins could be saturated with adverse hyperbolic meanings.

After two weeks in Dublin, Douglass's voice and hands worked incessantly to spread his ideas, and he was pleased with the favored reception of Dubliners. He wrote his wife that "for the first time ever maybe [...] he could properly inhabit his skin" (idem: 55). According to Anzieu postulates, the skin is the means of negotiation between body and mind to shape the subject. But to be recognized as a subject and develop one's identity it is necessary "continuity," employing Anzieu's term, which can be understood for our purposes as the affirmation of Douglass's subjectivity among strangers in a strange land by overcoming the past through present chance. It was not quite up to that occasion as his engraving on the cover of the Irish edition of his autobiography displayed a straight-nosed Douglass as "they wanted to remove the Negro from him" (idem: 50) - nonetheless, he liked the edition. There was still a way to go before he could assume a position of a subject of knowledge rather than "an object to be known" (Foucault 1977: 28). It means Douglass still needed to overcome fear and insecurity to embody his role of resisting the discourse of power invested on all slaves and become a protagonist of historical transformation and indeed keep his "mind unshackled" (McCann 2013: 45).

The Catholic north displayed a hunger-stricken devastated scenario of Ireland. Crossing dangerous roads after a "wrong” turn, Douglass came across a different Madonna a woman in grey and green rags dragging a bundle enclosing a child whose death she refused to accept: "You'll help my child, sir?" (idem: 73), she asks. The hungry woman was the personification of a grey-skied Ireland stricken by the Great Famine. Respected citizens of Eire were also on denial about their panorama "when he asked of the hunger that he had seen in the streets they said there was always a hunger in Ireland. She was a country that liked to be hurt" (idem: 70). The episode made Douglass feel as if "some axle inside him were broken" (idem: 75). The woman with the baby's image stuck to Douglass's mind evoking memories of advertisements about slaves in the United States: a fugitive girl, a man for sale, orphan children with "excellent teeth" (idem: 71). The famine and the potato blight 
appealed to his senses as they clung in the smell of the scented bath water Douglass was drowning in. Anzieu explains that although the sense of touch has primacy over the others, "all other sensory reflexivities [...] are modelled on the reflexivity of touch and so, later on, is the reflexivity of thought" (Anzieu 2016: 66). Douglass restlessness encapsulates an epiphanic moment when the gaps were narrower between hunger Irish and African Americans slaves, and his very objectives of advancing universal emancipation were growing more and more meaningful in him. Nonetheless, it would take more than soap to wipe the burden on ruined histories perpetrated on his dispirited mind.

In Cork, in the north, Douglass felt immersed in a chaotic sociopolitical context of Ireland where children appeared to be moving rags "marooned by hunger" (idem: 71). His hostess, Isabel, a committed citizen to the shortcomings of Ireland made Douglass more comfortable around people and felt encouraged to exercise his "true and proper voice" (idem: 85) and, despite a heavy heart, he acknowledged being "temporarily without chains" (ibidem). There is a moment in Isabel's household when Douglass forgot to be shirtless as he leaned out the window. Such an episode suggests that the libertarian was feeling at ease, free from the shame of displaying his blackness. His skin, no longer "enveloped" by fancy clothes, had started to suffice as people "didn't frighten him anymore" (idem: 93). Along the beach of Cork, Douglass felt homesick as it reminded him so much of Baltimore. He felt compelled to imprint his feet on the sand "over and over again, footprint after footprint" (idem: 95). Conversely, he allowed Ireland to be imprinted on him.

Douglass found a way of re-writing the black Atlantic once Knowing and Being tied a coherent knot in his mind. He chose visibility over elision by transcending ethnicity and nationality under the name of the collective human desire for emancipation, being it from hegemonic domination or from slavery itself, and his duty in this matter. He understood that the devastating outcomes of power are embodied on the ordinary people, no matter the color of their skin. Douglass embraced the contradictions of his history, which were the constant feelings of being free and captive at the same time. The more he could peacefully write against what held him enslaved, the more he felt that "the links lay in pieces at his feet" (ibidem). His enslaved body materialized the historical shortcomings and needed to be 
unchained, so his mind would also be free. But iron bonds ghostly clung to his mind setting a symbolic trap which held him subjected. Once able to find his voice, his body and mind overcame the dualism and amalgamated into an agential physical being. Douglass broke the boundaries between mind and body, by crossing the borders between himself and others and between black and white people. He transcended the power dominance invested on him and his people by solidifying a new discourse through his words and could once and for all inhabit his black skin.

\section{Works Cited}

Anzieu, Didier (2016), The Skin-Ego, trans. Naomi Segal, London, Karnac.

Foucault, Michel (1977), Discipline and Punish: The Birth of the Prison, trans. Alan Sheridan, New York, Vintage Books.

-- / Colin Gordon (1980), Power/Knowledge: Selected Interviews and Other Writings 19721977, trans. Colin Gordon et al., New York, Pantheon Books.

Gilroy, Paul (1993), The Black Atlantic: Modernity and Double-Consciousness, Massachusetts, Harvard University Press.

Jerônimo. Miguel B. / José Pedro Monteiro (2017), Internationalism, Imperialism and the Formation of the Contemporary World, Basingstoke, Palgrave Macmillan. 
Kinealy, Christine (2007), “The Liberator Daniel O'Connell and Anti-Slavery," History Today, vol. 57 , issue $12,51-57$.

McCann, Colum (2013), Transatlantic, New York, Random House.

\begin{abstract}
Alvany Guanaes holds a Ph.D. and a master's degree from the University of São Paulo in English Language literatures. The focus of her thesis was native canadian women autobiographical novels and her master's work was about the presentification of myths in Laguna Pueblo author Leslie Marmon Silko's Almanac of the Dead. Currently, she has been researching about empathy and foodways, focusing on the work of the Irish author Colum McCann. She has been giving literature lectures and workshops in several institutions and has been a teacher for over twenty-five years. Recently she has been accepted as a postdoctorate researcher at NOVA-FCSH.
\end{abstract}

